\title{
Research on Online Higher Art Education in the Internet Era
}

\author{
Zhiyong Chen \\ Hebei Normal University \\ Shijiazhuang, China
}

\author{
$\mathrm{Yu} \mathrm{Wu}$ \\ Hebei Normal University \\ Shijiazhuang, China
}

\begin{abstract}
Art education is a platform for overall art development and a cradle of artists. Art education in colleges is a backbone to guide art education development in the country. To well master the development situation of colleges in the country will play a deep role in the art education development in the country. Nowadays, there are a great number of art colleges independently established in the country, however, there are still many problems to be solved in art course arrangement in colleges. With the arrival of information era as well as the deep reform in higher education across the country, it has been a commonly shared opinion to develop an Internet-based new educational systems and teaching modes.
\end{abstract}

Keywords-higher art education; Internet; colleges; online education

\section{INTRODUCTION}

The development of higher art education in China needs the long term collaboration and unification between Chinese national culture and advanced cultures. Higher art education will need more time for research, thinking and learning in order to set an educational mode of its own and develop the art education. At the time of information, Internet-based education is the only way for higher art education, which cannot be replaced for the art education development in the country, doing good to guide the higher art education development and cultivate quality talents. Accordingly more attentions shall be paid to Internet-based art education, more investment shall be conducted to accelerate the reforms and continuously promote the all-round development of higher art education in the country.

\section{MAIN PROBLEMS OF Higher ART EDUCATION IN TRADITIONAL COURSE TEACHING}

On the one hand, all courses in higher art colleges are traditional and almost the same, there are few open courses. Most courses in art colleges are creative thought study, graphic design, aesthetics and professional drawing, etc. Some courses are very creative in name but old in class teaching. Second, class-based traditional teaching modes are stiff and old, failing to consider students' individual characteristics, interests and cognitive competences, which cannot stir students' thirst for knowledge. Actually modern education is also reflecting on the single class-based teaching mode and function, and more and more attentions have been paid to how to cultivate students' interests to learn and abilities of analyzing problems and understanding knowledge. In order to enable students to master key knowledge and individual characteristics turned to majors in a short time, many colleges have established studio systems in the country. The studio is based on class teaching, which can help students get professional knowledge and cultivate individual capabilities, stirring students' interests in art research and promoting the higher art education development. However, the studio mode is not widely used in stages of undergraduate education, second, some colleges which have established studio modes have not found suitable teaching mechanism. Many studios fail to well handle with the relations between studio's features, students' individual development and cultivation of students' self integration, unable to build a featured course structure aimed at a suitable art goal, and students cannot develop themselves in studios or develop art features of their own. In addition, the higher art education started later in the country, and the early art education was only following western teaching concepts, having no educational concepts of our own, besides, there are too few graduates who are willing to engage in art education, consequently most art teachers are poor in quality and get few accesses to art educational resources.

On the other hand, the concepts of art education theory are improperly transmitted, which block normal art teaching and development. During the exam-orientated education, most professional colleges are focused on examining students' plastic arts, and most courses in colleges are centered on cultivating capabilities of plastic arts, which have greatly influenced the art education development in the country. Most students hold a concept that plastic arts are key points, and the long term cultivation of plastic arts concepts have caused ossifications in thought to students, and individual arts features cannot be shown in creativity. More of art education is taken as a single skill education instead of art quality and culture, professional art colleges aim to cultivate world-class artists, besides, other colleges just copy that of professional art colleges, lacking nature or work division, which ultimately causes a simplified trend. Second, at present, most students are poor in art theory knowledge and general knowledge courses in colleges, which are related to the exam-orientated education and requirements on art students, as a result, the students get worse in theory knowledge after being admitted to professional colleges, besides, colleges are centered on training of professional courses, and students are occupied having no enough time for more theory learning. Many art students who 
want to further study are excellent in profession, yet failing to catch the chance due to poor theory knowledge.

\section{STATUS QUO AND DEVELOPING TRENDS OF INTERNET- BASED ONLINE EDUCATION}

In recent years, there are many newly rising Internet-based online education such as Tencent Class, New Orient Online Education and so on. Take Tencent Class as an example, there are all kinds of courses including IT, design, English, professional exams and more, it is easy to see that everyone can find resources to learn in Tencent Class, anytime and anywhere. In short, online education is an Internet-based learning mode, and some are certified and widely accepted such as adult exam online education, remote education and the like, most are attracting students through all kinds of certificates or diplomas. In addition to the above, there are many other online education platforms, which can be assessed by PC clients, website as well as APP. Such APPs carry Q\&A, key knowledge memory and so on, under the exam-orientated background in the country, the APPs are popular. Software developers take charge of collecting all kinds of exams and knowledge resources, then post on APPs, which can be used to test users, in the meantime, online interactions are also available, so they are greatly supported by many users especially students. Another kind of APP is widely downloaded by junior and senior middle school students, such as yuansouti.com. Such APP makes use of picture taking for search, and the problems that they know little about can be searched for specific answers.

All of the above belong to online education, it is not difficult for us to see that relying on convenience, rapidness, high interaction, break-through limitation in time and space and fragmented learning through mobile clients, online education makes diversify teaching contents and has a bright perspective, meeting the current educational and teaching demands in the country. Online education helps realize allround exchanges and learning through network between teaches and students, and students, shortening the psychological distance between each other, promoting exchanges and learning effect. However, there are still some potential problems related to the online education that we should pay more attentions to. Educational consumption can be seen as a loss of time, actually it is closely related to the future development and even life of students, most are impossible to have twice chances to take exams of senior high school entrance examination, college entrance examination, postgraduate qualifying examination, needless to say how to select colleges. Therefore, whether parents or students themselves, when selecting auxiliary classes, both are very careful, they will generally compare the classes, listen to trial teaching or investigate in situ, almost nobody immediate pay to sign up for before seeing carefully online. These are just major factors blocking the online education development, generally speaking, at the current time of information technology developing rapidly in China, online education platforms, where poor or predominant, may renew students' learning concepts and modes, which cannot be ignored, which is just the same as current higher art education, and it can drive the higher art education development in the country.

\section{THOUghts OF INTERNET-BASED ONLINE HIGHER ART EDUCATION}

Online higher art education, based on traditional higher art education, is a teaching means that can spread widely.

First of all, seen from teaching contents, plans and educational structure, online education and art education suit each other. With regard to art education in colleges, the multimedia courses rising in recent years only make the class interesting and feasible in experience, yet the short time class is unable to make students fully feel the charm of art. However, with Internet introduced, on the one hand, students may repeat the online learning; on the other hand, promotion and supervision can be achieved between teachers and students through network. In recent years, online education has made great progress, and more and more people turn to online education, which is convenient, rapid and selectable. Online home instruction is just one of the forms. Such one to one online education solves the inconvenience of information communication for traditional home instructions, bringing great convenience to communication, exchanges and information feedback between teachers and students. Art education is not just one-to-one drawing skill training, and at the time of quality education, more attentions shall be paid to art cultural attainments as well. The online home instruction and online education make it easy for students who want to further study get art theory knowledge at any time, the students who receive higher education look up data online in spare time, seeking partners sharing interests, online discussion in order to improve individual professional capabilities. Higher art education is not just an education to students and also a retraining to teachers. With the art education development, it is often found that teachers are unable to fit the situations. The online education may enable teachers to learn professional skills in their spare time, or anytime, anywhere, and improve the communication and teaching quality with colleges and students through network. In addition, teachers are encouraged to create online teaching public resources database, develop excellent teaching of their own and showing the teaching strength of their own. Based on the above, teachers may have their capabilities improved during the teaching, getting more professional knowledge and fitting modern quality education so as to cultivate more quality art talents.

Second, galleries and exhibition halls are an important part of art education, many diverse galleries and exhibition halls can be found in foreign art colleges, which are artistic manifestation and image display. In addition to professional courses, these are important channels for students to access to what they have learned and a drill for students to simulate real artists in a real social environment, just like medical college students who can practice in hospitals to contact patients, and educational institute students who can teach students in colleges. Through accessing to such galleries or exhibitions or other art activities, art students may have practical skills improved, which also improve professional skills of their own. With a great number of population yet limitation in field in the country, it is very difficult to make every students participate in such exhibition activities. However, at the time of Internet, such exhibitions can be realized and promoted online, and every student may create professional art promotion channel of 
his or her own, which will be maintained by colleges regularly to prevent uncontrolled and unstable art education spread online.

\section{CONCLUSION}

Online education is not only a course setting but also a new teaching means fit for the current quality education situation in the country. The modern online education may solve the malpractice in teaching such as single and poor teaching means in higher art education in the country. And it is an open education which can meet the needs of anyone at any time, anywhere, or whichever or whatever to learn, having features of learning actively and meeting the current needs of quality education in the country. Traditional teaching in art education limits the application of diverse multimedia means, yet online education can cooperate with traditional teaching for diverse teaching. Due to traditional and narrow concept in art education, the art education is almost the same as artistic skill education, and we should be kept mindful for such mouth to ear teaching which is focused on skills but ignoring cultural education. In order to cultivate students' capabilities of artistic appreciation and creativity, with traditional art teaching inherited, we should make full use of scientific learning tools at the time of Internet, well integrate educational resources and Internet technology, introduce online education innovative products with higher interaction and individual learning encouraged in order to build a real online learning platform which is full of artistic atmosphere, humane atmosphere and academic atmosphere. Such views mentioned above are expected to spur the development of higher art education or promote art teachers to conduct researches or innovation, or provide references for students of higher art education, all of these will help Chinese higher art education go on a healthy way and place a solid foundation for cultivating more and allsided art talents.

\section{REFERENCES}

[1] Guo Xiao, Zhang Yong, Overlooking from the Commanding Height of Art Education, Yunnan University Press, 2010.

[2] Cheng Chunyun, Introduction to Art Education, Yunnan University Press, 2011.

[3] Deng Lan, Teaching Art for Art Teaching, Ji'nan University Press, 2011.

[4] Du Dakai, Contemporary Situation of Art Education, Tsinghua University Press, 2009.

[5] Huang Mingfen, Internet Art Industry, Academia Press, 2007.

[6] Guo Shengjian, On Art Education, Shanghai Educational Publishing House, 1999

[7] Subject Course Reform and Teaching Innovation: Art Teaching Principle and International Art Education Practices, Xueyuan Audio \& Video Press, 2004. 